\title{
Article \\ Effects of Hydrothermal and Microwave Dual Treatment and Zein on the Enzymolysis of High Amylose Corn Starch
}

\author{
Jie Liu ${ }^{1}$, Qiuye Yang ${ }^{1}$, Tiantian Yuan ${ }^{1}$, Yawei Liu ${ }^{1, * \mathbb{C}}$ and Guihong Fang ${ }^{2,3, *}$ \\ 1 College of Food Science and Engineering, Henan University of Technology, Zhengzhou 450001, China; \\ liujie@haut.edu.cn (J.L.); 15904927191@163.com (Q.Y.); yuantiantian0226@163.com (T.Y.) \\ 2 Department of Nutrition and Food Hygiene, Hainan Medical University, Haikou 571199, China \\ 3 School of Food Science and Engineering, South China University of Technology, Guangzhou 510640, China \\ * Correspondence: liuyaweihaut@163.com (Y.L.); fgh19801206@163.com (G.F.); \\ Tel.: +86-0371-6775-8022 (Y.L.); +86-0898-6689-3776 (G.F.)
}

check for

updates

Citation: Liu, J.; Yang, Q.; Yuan, T.; Liu, Y.; Fang, G. Effects of Hydrothermal and Microwave Dual Treatment and Zein on the Enzymolysis of High

Amylose Corn Starch. Gels 2022, 8, 29. https: / / doi.org/10.3390/gels 8010029

Academic Editors: To Ngai and

Fuguo Liu

Received: 30 November 2021

Accepted: 29 December 2021

Published: 4 January 2022

Publisher's Note: MDPI stays neutral with regard to jurisdictional claims in published maps and institutional affiliations.

Copyright: (C) 2022 by the authors. Licensee MDPI, Basel, Switzerland. This article is an open access article distributed under the terms and conditions of the Creative Commons Attribution (CC BY) license (https:// creativecommons.org/licenses/by/ $4.0 /)$.

\begin{abstract}
Resistant starch (RS) type 2-high-amylose corn starch (HACS) was subjected to simultaneous hydrothermal $\left(25 \%\right.$ moisture content, $90{ }^{\circ} \mathrm{C}$ for $12 \mathrm{~h}$ ) and microwave ( $35 \%$ moisture content, $40 \mathrm{~W} / \mathrm{g}$ microwaving for $4 \mathrm{~min}$ ) treatment and zein (at a zein to treated starch ratio of $1: 5,50{ }^{\circ} \mathrm{C}$ for $1 \mathrm{~h})$ to improve its resistance to enzymolysis. Scanning electron microscopy (SEM) highlighted the aggregation and adhesion of the composite. The average particle size of the composite $(27.65 \mu \mathrm{m})$ was exceeded that of both the HACS $(12.52 \mu \mathrm{m})$ and the hydrothermal and microwave treated HACS (hydro-micro-HACS) $(12.68 \mu \mathrm{m})$. The X-ray diffraction results revealed that the hydro-micro-HACS and composite remained B-type, while their crystallinity significantly decreased to $16.98 \%$ and $12.11 \%$, respectively. The viscosity of the hydro-micro-HACS and composite at $50{ }^{\circ} \mathrm{C}$ was $25.41 \%$ and $35.36 \%$ lower than that of HACS. The differential scanning calorimetry (DSC) results demonstrated that the composite displayed a new endothermic peak at $95.79{ }^{\circ} \mathrm{C}$, while the weight loss rate and decomposition temperature were $7.61 \%$ and $2.39 \%$ lower than HACS, respectively. The RS content in HACS, the hydro-micro-HACS, and composite was $47.12 \%, 57.28 \%$, and $62.74 \%$, respectively. In conclusion, hydrothermal and microwave treatment combined with zein provide an efficient physical strategy to enhance the RS type 2-HACS.
\end{abstract}

Keywords: high-amylose corn starch; hydrothermal treatment; microwave treatment; zein; enzymolysis; resistant starch

\section{Introduction}

The increase in consumer demand for healthy food products has led to new food processing and composition requirements. The protein-starch composite can be used as biological material in the food industry [1], the medical field, environmental protection, and textiles [2]. The protein-starch composite displays unique processing, anti-oxidative and anti-digestive properties, as well as other functional characteristics as food additives and ingredients [3].

Although resistant starch (RS), also known as anti-enzymatic starch, cannot be digested and absorbed in the small intestine, it can be fermented by the microbial flora in the colon. It presents beneficial physiological effects [4], such as regulating blood sugar levels, significantly improving intestinal health, preventing intestinal disease and colon cancer [5], and reducing cholesterol levels. RS is also considered a component of dietary fiber. Compared with traditional dietary fiber, RS presents advantages, such as a delicate taste, low water holding capacity, and low calorific content. Therefore, it is widely used in bread, tortillas, snack products, and fried foods to lower the glycemic index and as a food thickener in sauces, soups, and beverages without affecting the taste and flavor [6]. Furthermore, RS is classified into four types according to its resistance to enzymatic hydrolysis [7]. The starch granules of RS1 are wrapped by cell walls and protein [8]. RS2 displays a dense 
molecular structure of natural starch granules, making enzymes inaccessible. The RS in RS3 is formed via starch retrogradation after gelatinization. RS4 represents chemically modified starches, such as ethers and esters. Additionally, RS5 denotes a starch-lipid V-type complex [9]. As a high amylose corn starch (HACS), RS2 does not gelatinize during cooking [10]. Hydrothermal and microwave treatment represent two effective methods to increase RS content [11]. Storing starch at a low temperature $\left(-20^{\circ} \mathrm{C}\right)$ after hydrothermal treatment can significantly increase the RS content in retrograded products. Zhang et al. indicated that the RS content of canna starch doubled at a $20 \%$ moisture content level and a microwave power of $1000 \mathrm{~W}$ for $30 \mathrm{~min}$ [12]. Son Trinh Khanh et al. revealed that the slowly digestible starch (SDS) content of starch treated at a 30\% moisture content level for $24 \mathrm{~h}$ reached $49.1 \%$, which was $31.9 \%$ higher than in the control group after the hydrothermal treatment of water yam starch [13]. Molavi et al. reported that hydrothermal treatment increased starch solubility and gelatinization temperatures, especially the onset temperature (To), but decreased swelling power and amylose leaching, relative crystallinity, gelatinization enthalpy, and gelatinization range [14]. Andrade reported similar results after subjecting cassava starch to hydrothermal treatment [15]. Li et al. reported that microwave-toughening treatment increased the amylose and RS content of potato starch from $26.08 \%$ and $11.54 \%$ to $35.06 \%$ and $27.09 \%$, respectively [16]. Fan et al. found that the crystallinity of microwave-treated rice and potato starch decreased to some extent while displaying lower amorphous layer thickness and increased crystalline layer thickness [17]. Wei et al. reported that microwave and hydrothermal treatment decreased the solubility and swelling power of water caltrop starch. The water caltrop starch presented a C-type crystalline pattern which changed into an A-type pattern after microwave treatment. After $50 \mathrm{~s}$ of microwave treatment, this starch displayed the highest amylose $(48.78 \%)$, crystallinity $(42.95 \%)$, and RS content $(67.41 \%$, uncooked and $48.91 \%$, cooked) [18]. Zailanithe et al. showed that microwave-modified sago (Metroxylon sagu) starch exhibited higher RS levels [19].

Zein is a yellow powder belonging to a class of prolamins and is applied in coatings, films, fibers, plastics, adhesives, and inks [20]. Zein can encapsulate starch granules after freeze-drying and low-temperature spray drying to increase their anti-digestive properties [21]. Combining proso millet with zein decreased the rapidly digestible starch (RDS) content while increasing the SDS and RS levels [22]. Moreover, hydrothermal treatment, corn oil, and zein significantly increased the SDS and RS content in the composite [23]. Gao et al. indicated that the gelatinization temperature and final viscosity value of a waxy corn starch and zein composite decreased, while the storage modulus value, enthalpy value, and thermal stability increased [24]. Zein may positively impact the rheological properties of dough and consequently the development of strain hardening behavior [25]. Studies have shown that the enzymatic hydrolysis of zein can change the nutritional and functional properties of food proteins, such as improving digestibility, modifying sensory quality (such as texture or taste), enhancing antioxidant activity, and reducing allergenicity [26]. However, limited information is available regarding the impact of physical treatment and zein on the RS content. This study investigates the modification effect of combining hydrothermal, microwave, and zein treatments on the enzymolysis of high-amylose corn starch, providing an alternative method for RS preparation.

\section{Results and Discussion}

\subsection{Morphological Characteristics}

HACS granules are mostly round or oval, while a few are rod-shaped with smooth surfaces (Figure 1A). The high-amylose corn starch granules were independent of each other and showed no adhesion after hydrothermal and microwave treatment (Figure 1B). Furthermore, the granule morphology was not modified, which was consistent with the results observed by Vamadevan et al. who subjected corn starch granules to hydrothermal treatment [27]. Zhong et al. found that no changes were evident in the size and shape of the HACS after microwave treatment [28], while the zein and treated starch composite showed agglomeration. The starch granules were wrapped by a continuous phase formed by zein 
(Figure $1 C, \times 3000$, Figure $1 D, \times 10,000)$. In a previous study, a composite was prepared consisting of hydroxypropyl tapioca starch and zein. The results showed that an increased zein level or reaction time caused the starch granules to adhere to or be wrapped by the zein and were even embedded in the zein matrix [29]. Leroy et al. observed the dispersion of large starch aggregates into a continuous zein matrix at a zein content level exceeding $50 \%$ [30]. The zein was aggregated and distributed on the surface of the starch granules due to its precipitation after adding cold water. Therefore, the starch granules were protected, inhibiting the enzymatic action.

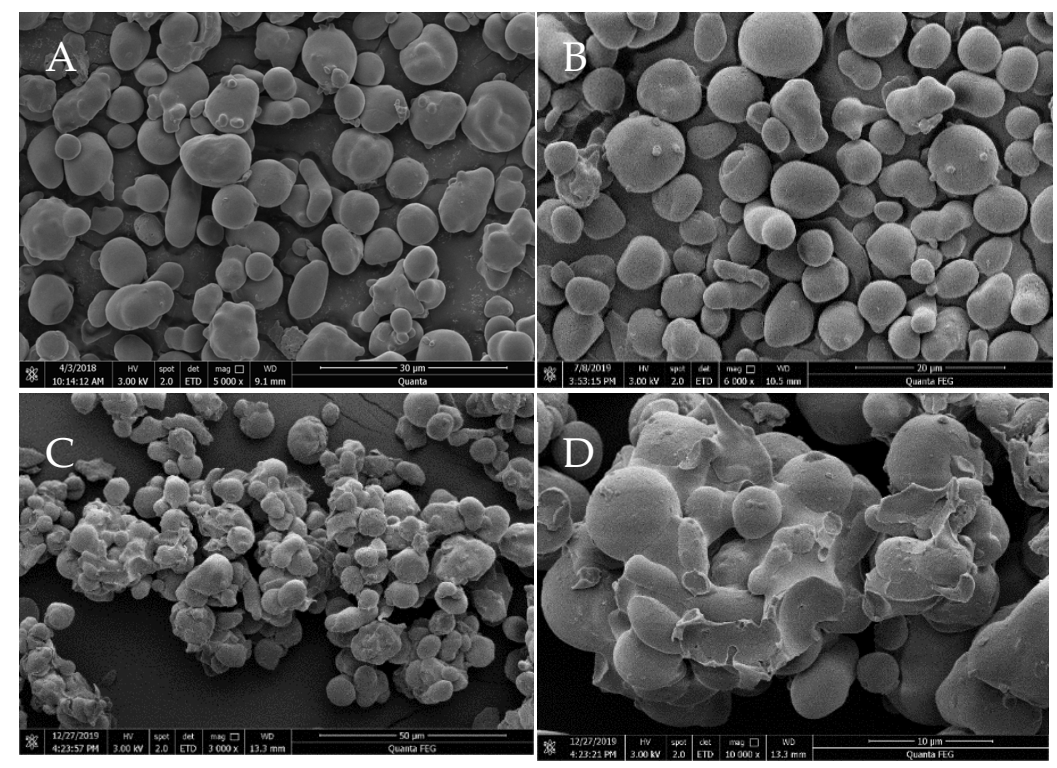

Figure 1. Scanning electron micrographs of the HACS ((A): 5000 $\times$ magnification), hydro-micro-HACS ((B): $6000 \times$ magnification), and the composite $((\mathbf{C}, \mathbf{D}): 3000 \times$ and $10,000 \times$ magnification).

\subsection{Color}

No significant differences were evident between the redness $\left(\mathrm{a}^{*}\right)$ values of the three samples $(p>0.05)$ (Table 1$)$. The HACS presented higher yellowness $\left(b^{*}\right)$ values, while lower $L^{*}$ values were evident in the hydro-micro-HACS $(p<0.05)$ (Table 1$)$. This experiment used commercial yellow zein containing a high xanthophyll pigment concentration (8-9\%), consequently increasing the $b^{*}$ values and decreasing the lightness $\left(L^{*}\right)$ values of the composite. The konjac glucomannan and zein composite gel presented a yellow color [31].

Table 1. Color, particle sizes, viscosity, thermal gravimetric analyzer (TGA) characteristics, and crystallinity of the HACS, hydro-micro-HACS, and composite.

\begin{tabular}{|c|c|c|c|c|c|c|c|c|}
\hline Sample & $a^{*}$ & $\mathbf{b}^{*}$ & $\mathbf{L}^{*}$ & $\begin{array}{l}\text { Particle } \\
\text { Size/ } / \mu \mathrm{m}\end{array}$ & Viscosity/cP & $\begin{array}{c}\text { Weight Loss } \\
\text { Rate/\% }\end{array}$ & $\begin{array}{l}\text { Decomposition } \\
\text { Temperature } /{ }^{\circ} \mathrm{C}\end{array}$ & Crystallinity/\% \\
\hline HACS & $-1.23 \pm 0.01 \mathrm{a}$ & $9.32 \pm 0.01 b$ & $97.02 \pm 1.01 \mathrm{a}$ & $12.52 \pm 1.06 \mathrm{~b}$ & $362 \pm 1.00 \mathrm{a}$ & $80.99 \pm 1.11 \mathrm{a}$ & $316.98 \pm 2.08 b$ & $20.87 \pm 0.15 a$ \\
\hline $\begin{array}{c}\text { Hydro-micro- } \\
\text { HACS }\end{array}$ & $-1.24 \pm 0.01 \mathrm{a}$ & $9.33 \pm 0.02 b$ & $97.03 \pm 0.99 \mathrm{a}$ & $12.68 \pm 0.01 b$ & $270 \pm 3.00 \mathrm{~b}$ & $80.29 \pm 0.50 \mathrm{a}$ & $317.84 \pm 1.09 \mathrm{a}$ & $16.98 \pm 0.23 b$ \\
\hline Composite & $-1.24 \pm 0.02 \mathrm{a}$ & $20.90 \pm 3.01 \mathrm{a}$ & $94.10 \pm 2.02 b$ & $27.65 \pm 2.96 \mathrm{a}$ & $234 \pm 3.00 c$ & $74.83 \pm 2.30 \mathrm{~b}$ & $309.41 \pm 2.10 \mathrm{c}$ & $12.11 \pm 0.12 \mathrm{c}$ \\
\hline
\end{tabular}

Mean \pm SD values. Different lowercase letters after the number in the same column indicate a significant difference $(p<0.05) . \mathrm{a}^{*}$, redness; $\mathrm{b}^{*}$, yellowness; $\mathrm{L}^{*}$, lightness.

\subsection{Particle Size}

The average particle sizes in HACS, hydro-micro-HACS, and the composite were $12.52,12.68$, and $27.65 \mu \mathrm{m}$, respectively (Table 1). Hydrothermal and microwave treatment did not significantly change the particle sizes of HACS $(p>0.05)$. Luo et al. reported that microwave treatment did not alter the sizes and shapes of the granules in normal maize, waxy maize, and amylomaize V starches [32], while those of the composite increased 
significantly $(p<0.05)$, which was consistent with the scanning electron micrographs. The encapsulation of the protein around starch granules causes agglomeration, increasing their average particle sizes [29].

\subsection{X-ray Diffraction}

The X-ray diffraction patterns of HACS, hydro-micro-HACS, and composite presented diffraction peaks at $2 \theta$ of $5.6^{\circ}, 17^{\circ}, 19.5^{\circ}, 22^{\circ}$, and $24^{\circ}$ (Figure 2 ). These peaks were characteristic of a B-type X-ray pattern, indicating that the hydrothermal and microwave treatment and the addition of zein did not change the crystalline structure in high-amylose corn starch. The absorption intensity of the diffraction peaks decreased after dual treatments (16.98\% crystallinity) and further zein addition (12.11\% crystallinity) (Table 1). Molavi et al. and Pinto et al. reported that although hydrothermal treatment reduced the relative crystallinity of acorn starch, it did not alter the X-ray diffraction pattern [14,33]. Furthermore, hydrogen bond breakage during hydrothermal treatment caused starch crystallite disruption [11]. Yin et al. and Ma et al. showed that microwave treatment decreased the crystallinity of laird lentil starch $[34,35]$. These results indicated that microwave treatment disrupted the intra- and inter-molecular hydrogen bonding in starch, damaging the doublehelical structure and destroying the crystalline arrangement [36]. Furthermore, the zein partially replaced the starch in the complex, weakening the absorption peak intensity.

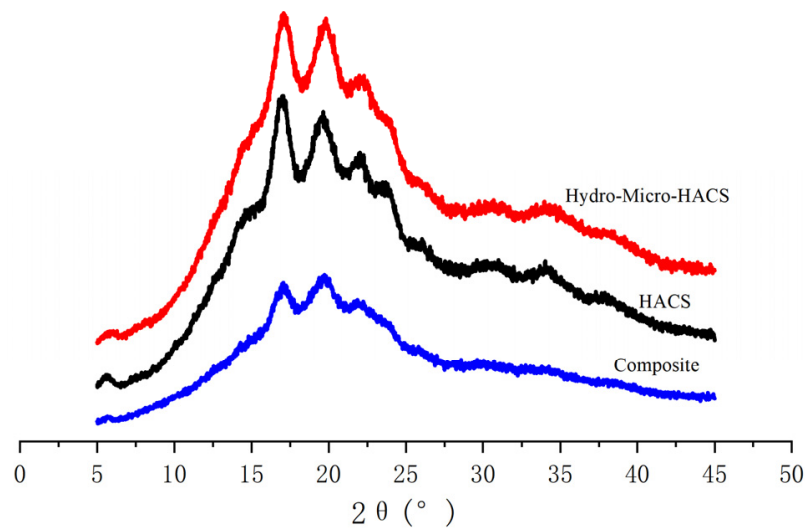

Figure 2. The X-diffraction patterns of the HACS, hydro-micro-HACS, and composite. Different letters following the crystallinity value indicate significant differences $(p<0.05)$.

\subsection{Viscosity}

The HACS, hydro-micro-HACS, and composite viscosity were 362, 270, and $234 \mathrm{cP}$, respectively. An increase in the viscosity of the paste during the heating phase of gelatinization indicated the water absorption level and swelling capacity of the starch [37], while a viscosity increase during the cooling phase was attributed to the hydrogen bond aggregation of the amylose [38]. Pinto et al. indicated that hydrothermally treated starch showed lower peak viscosity than the native starch [33]. The viscosity peak, viscosity at holding $\left(95^{\circ} \mathrm{C}\right)$ and cooling periods $\left(50^{\circ} \mathrm{C}\right)$, setback, and consistency of canna starch decreased compared to its native starch counterpart [39]. Hydrothermal and microwave treatment reduced the viscosity of HACS at $50{ }^{\circ} \mathrm{C}$, indicating a lower tendency for retrogradation [40]. Mutlu et al. [41] demonstrated that microwave treatment caused low cold viscosity. The composite exhibited the lowest viscosity of the three samples, indicating that zein further inhibited starch molecule retrogradation.

\subsection{Thermal Properties}

The weight loss rate of the HACS, hydro-micro-HACS, and composite was $80.99 \%$, $80.29 \%$, and $74.83 \%$ (Table 1 ), respectively, while no significant differences were evident between HACS and hydro-micro-HACS $(p>0.05)$. The significant decrease in the weight loss rate of the composite may be due to the zein and starch combination. At maximum HACS, 
hydro-micro-HACS, and composite decomposition rates, the decomposition temperatures were $316.98,317.84$, and $309.41^{\circ} \mathrm{C}$, respectively. The increased decomposition temperature during the dual treatments $(p<0.05)$ indicated enhanced thermal stability, while the internal molecule structure became firmer. The decreased decomposition temperature of the composite may be caused by the partial replacement of the starch by zein.

The hydro-micro-HACS showed a significant increase in the To and peak gelatinization temperature $(\mathrm{Tp})$ compared to HACS $(p<0.05)$ (Table 2$)$. Dual treatment significantly decreased $(p<0.05)$ the energy required for gelatinization $(\Delta \mathrm{H})$. The subsequent increase in the To and $\mathrm{Tp}$ and decrease in $\Delta \mathrm{H}$ were consistent with the modification results obtained in waxy maize starch via hydrothermal treatment and crosslinking [42]. Hydrothermal treatment led to a perfect and less crystalline structure [43]. Molavi et al. reported that increased gelatinization temperatures might be related to amylose-amylose and amyloseamylopectin interaction since the amylose leaching decreased significantly $(p<0.05)$ after hydrothermal treatment [14]. The composite presented two peaks after zein addition. The first endothermic peak occurred at a To of $84.77^{\circ} \mathrm{C}$ and a completion gelatinization temperature $(\mathrm{Tc})$ of $104.97^{\circ} \mathrm{C}$, while the second endothermic peak was evident between a To of $134.76{ }^{\circ} \mathrm{C}$ and a Tc of $138.62{ }^{\circ} \mathrm{C}$ (Table 2). The temperatures of the second endothermic peak of the composite were the same as the treated starch $(p>0.05)$, while the $\Delta H$ decreased significantly $(p<0.05)$. The decreased $\Delta \mathrm{H}$ could be attributed to the partial replacement of the treated starch by zein. Therefore, the starch concentration was reduced, and less energy was required to destroy the crystalline structure during gelatinization [44].

Table 2. DSC data of the HACS, hydro-micro-HACS, and composite.

\begin{tabular}{|c|c|c|c|c|c|c|c|c|}
\hline \multirow{2}{*}{ Sample } & \multicolumn{4}{|c|}{ Peak1 } & \multicolumn{4}{|c|}{ Peak2 } \\
\hline & $\mathrm{To} /{ }^{\circ} \mathrm{C}$ & $\mathrm{Tp} /{ }^{\circ} \mathrm{C}$ & $\mathrm{Tc} /{ }^{\circ} \mathrm{C}$ & $\Delta \mathrm{H}(\mathrm{J} / \mathrm{g})$ & To $/{ }^{\circ} \mathrm{C}$ & $\mathrm{Tp} /{ }^{\circ} \mathrm{C}$ & $\mathrm{Tc} /{ }^{\circ} \mathrm{C}$ & $\Delta \mathbf{H}(\mathrm{J} / \mathrm{g})$ \\
\hline HACS & - & - & - & - & $132.95 \pm 0.10 \mathrm{~b}$ & $133.05 \pm 0.15 b$ & $139.16 \pm 0.11 \mathrm{a}$ & $13.34 \pm 0.10 \mathrm{a}$ \\
\hline $\begin{array}{l}\text { Hydro-micro- } \\
\text { HACS }\end{array}$ & - & - & - & - & $134.78 \pm 0.18 \mathrm{a}$ & $135.39 \pm 0.10 \mathrm{a}$ & $138.61 \pm 0.09 \mathrm{~b}$ & $6.78 \pm 0.12 b$ \\
\hline Composite & $84.77 \pm 0.23$ & $95.79 \pm 0.21$ & $104.97 \pm 0.14$ & $6.91 \pm 0.20$ & $134.76 \pm 0.04 \mathrm{a}$ & $135.23 \pm 0.12 \mathrm{a}$ & $138.62 \pm 0.02 b$ & $5.65 \pm 0.34 c$ \\
\hline
\end{tabular}

Mean \pm SD values. Different lowercase letters following the numbers in the same column indicate significant differences $(p<0.05)$.

\subsection{Enzymolysis}

The RS levels in the samples were used to characterize the degree of enzymatic hydrolysis. The RS content in HACS, hydro-micro-HACS, and composite was $47.12 \%, 57.28 \%$, and $62.74 \%$, respectively. The hydrothermal and microwave treatment and compounded zein increased the RS by $21.56 \%$ and $33.15 \%$, respectively. Brumovsky and Thompson found that hydro-micro-HACS displayed a resistance level of $43.9 \%$ compared to native starch at $18.4 \%$ [45]. Zhong et al. indicated that HACS subjected to microwave treatment for $1 \mathrm{~min}$ displayed a lower degree of hydrolysis than the native sample [28]. Sun et al. speculated it might be challenging for microwave-treated samples to make contact with digestive enzymes, decreasing the hydrolysis rate [46]. The perfect crystalline structure resulting from hydrothermal and microwave treatment increased the gelatinization difficulty and enzymatic hydrolysis of RS 2 [42]. The presence of zein in the composite further hampered gelatinization and hydrolysis from its spatial barrier to the enzyme. Xu et al. showed that the physical barrier of the zein matrix restricted water ingress, heat transfer, and adequate space for granule swelling, consequently preventing the enzyme access to the starch [21]. Kljak et al. reported that the starch digestibility rate decreased when zein was present in the starch. When starch granules were embedded in a complex matrix, zein limited their accessibility to enzymes, influencing the starch digestibility rate [47].

\section{Conclusions}

Hydrothermal and microwave treatment and zein increase the RS content in HACS by $21.56 \%$ and $33.15 \%$, respectively. Hydrothermal and microwave treatment decreases the crystallinity, viscosity, and $\Delta \mathrm{H}$ of HACS by $16.98 \%, 25.41 \%$, and $49.18 \%$, respectively. 
The zein encapsulation of the modified starch granules increases the average particle sizes and $\mathrm{b}^{*}$ value of the composite by $118 \%$ and $124 \%$. The crystallinity, viscosity, lightness, weight loss rate, and decomposition temperature of the composite decrease by $28.68 \%$, $13.33 \%, 3.02 \%, 6.80 \%$, and $2.65 \%$, respectively. The results reveal that hydrothermal and microwave treatment perfected the crystalline structure of the starch granules, while zein encapsulation facilitates enzymatic hydrolysis. Therefore, developing a new method for RS preparation is essential, and further exploration of the application in various food matrices is required.

\section{Materials and Methods}

\subsection{Materials}

The HACS was supplied by Hengrui Technology Co., Ltd. (Luohe, China). The RS test kits were acquired from Ireland Megazyme Company, and zein was purchased from Sinopharm Chemical Reagent Co., Ltd. (Shanghai, China). The anhydrous ethanol was obtained from Tianli Chemical Reagent Co., Ltd. (Tianjin, China), while the sodium hydroxide was purchased from Tianjin Kemeo Chemical Reagent Co., Ltd. (Tianjin, China).

\subsubsection{Preparation of the Hydro-Micro HACS}

Hydrothermal treatment occurred according to a method described by Sui et al. [48]. The moisture content of the HACS was adjusted to $25 \%$ with distilled water after equilibration at room temperature for $24 \mathrm{~h}$. The sample was placed in a sealed high-temperatureresistant glass bottle and dried at $90^{\circ} \mathrm{C}$ for $12 \mathrm{~h}$, after which it was refrigerated at $4{ }^{\circ} \mathrm{C}$ for $10 \mathrm{~h}$. The refrigerated HACS dried at $40{ }^{\circ} \mathrm{C}$ to a moisture content of $10 \%$.

After hydrothermal treatment, the moisture content of the HACS was adjusted to $35 \%$ with distilled water and equilibrated at room temperature for $24 \mathrm{~h}$. The sample was microwaved at $40 \mathrm{~W} / \mathrm{g}$ for $4 \mathrm{~min}$ and refrigerated at $4{ }^{\circ} \mathrm{C}$ for $10 \mathrm{~h}$, after which it was dried at $40{ }^{\circ} \mathrm{C}$ to a moisture content of $10 \%$. The samples were ground and sieved using an 80-mesh sieve for further analysis.

\subsubsection{Preparation of the Zein and Hydro-Micro HACS Composite}

Zein $(6 \% w / w)$ was dissolved in ethanol $(70 \%)$ and stirred in a water bath at $30{ }^{\circ} \mathrm{C}$ until completely dissolved. Then, hydro-micro-HACS (at a 1:5 ratio of zein to starch) was slowly added while rapidly stirring in a $50{ }^{\circ} \mathrm{C}$ water bath for $1 \mathrm{~h}$. Next, cold water was added at 80 times the protein content, stirred quickly for $30 \mathrm{~min}$, and allowed to settle. After removing the supernatant solution, the precipitate was dried at $45^{\circ} \mathrm{C}$, ground, and sieved using an 80-mesh sieve for further analysis.

\subsection{Scanning Electron Microscopy (SEM)}

The HACS, hydro-micro-HACS, and composite surfaces were observed and recorded using SEM (Quanta250 FEG, FEI, Hillsboro, OR, USA) at an accelerating voltage of $3 \mathrm{kV}$ in high-vacuum conditions.

\subsection{Color}

The color of the HACS, hydro-micro-HACS, and composite was measured using a Konica Minolta colorimeter CR-400 (Osaka, Japan) and the $\mathrm{L}^{*}$ (the degree of lightness), $a^{*}$ (the red-green axis), and $b^{*}$ (the yellow-blue axis) values were recorded.

\subsection{Particle Size}

The HACS, hydro-micro-HACS, and composite particle size distributions were determined using a laser diffraction particle size analyzer (SALD-301V, SHIMADZU, Kyoto, Japan).

\subsection{X-ray Diffraction}

The X-ray diffraction patterns were determined using an X-ray diffractometer (Rigaku MiniFlex600, Tokyo, Japan) at a scanning speed of $4^{\circ} / \mathrm{min}$, angles ranging from $5^{\circ}$ to $45^{\circ}$ 
(2ө), $40 \mathrm{kV}$, and $30 \mathrm{~mA}$. The MDI Jade 6.0 software (Material Date, Inc., Livermore, CA, USA) was used to analyze the crystallinity of the samples.

\subsection{Viscosity}

The HACS, hydro-micro-HACS, and composite were mixed with distilled water to obtain slurries $(6 \%, w / v)$, which were placed in separate sealed bottles. The samples were gelatinized in an autoclave at $126^{\circ} \mathrm{C}$ for $30 \mathrm{~min}$, while their viscosity levels were measured at $50{ }^{\circ} \mathrm{C}$ using a DV-III rotary viscometer.

\subsection{Thermal Properties}

The HACS, hydro-micro-HACS, and composite thermal characteristics were measured using a thermogravimetric analyzer (TGA; Q50, TA, Instruments, New Castle, DE, USA) and differential scanning calorimeter (DSC; Q20, TA, New Castle, DE, USA). The sample $(10 \mathrm{mg}, \mathrm{db})$ was placed in a platinum pan and heated from $40{ }^{\circ} \mathrm{C}$ to $600{ }^{\circ} \mathrm{C}$ at a heating rate of $10^{\circ} \mathrm{C} / \mathrm{min}$ to obtain the weight loss and weight loss rate values. The composite $(2.5 \mathrm{mg}, \mathrm{db})$ was mixed with $7.5 \mu \mathrm{L}$ in an aluminum pan, which was hermetically sealed and equilibrated at room temperature for $24 \mathrm{~h}$. The sample and reference were scanned from $20^{\circ} \mathrm{C}$ to $160^{\circ} \mathrm{C}$ at a heating rate of $10^{\circ} \mathrm{C} / \mathrm{min}$.

\subsection{Enzymolysis}

The HACS, hydro-micro-HACS, and composite enzymolysis were determined using a Megazyme RS detection kit [4]. The sample $(100 \mathrm{mg})$ was incubated in a solution containing pancreatic amylase and amyloglucosidase in a water bath at $37^{\circ} \mathrm{C}$ for $16 \mathrm{~h}$, after which an equal volume of ethanol was added to terminate the reaction. The solution was centrifuged, and the supernatant was discarded, after which the precipitate was washed twice with ethanol. The precipitated flocs were placed in an ice water bath, dissolved by adding $2 \mathrm{M} \mathrm{KOH}$, and stirred vigorously with a magnetic stirrer. The solution was adjusted to neutral with acetate buffer, and the starch was quantitatively hydrolyzed into glucose with Aufrecht Melcher Grossaspach (AMG), after which the glucose content of the sample was measured using a glucose oxidase-preoxidase (GOPOD)kit. The RS content was calculated as the free glucose product released via RS hydrolysis using amyloglucosidase with a correction factor of $0.9, \mathrm{RS}=$ glucose $\times 0.9$.

$$
w=\frac{\mathrm{E} \times \mathrm{F} \times 0.9}{\mathrm{~W}} \times 100 \%
$$

where $w$ denotes the RS content (\%), E is the absorbance difference between the sample and the blank reagent, $\mathrm{F}$ signifies the conversion from the absorbance value to the micrograman absorbance value of $100 \mu \mathrm{g}$ D-glucose was determined during the GOPOD reaction, $\mathrm{F}=100$ (the number of $\mu \mathrm{g}$ of D-glucose divided by the GOPOD absorbance value of $100 \mu \mathrm{g}$ $\mathrm{D}$-glucose), and $\mathrm{W}$ is the dry starch weight $(\mathrm{g})$.

The RS levels were used to characterize the HACS, hydro-micro-HACS, and composite enzymolysis. The RS content in the composite was calibrated using the starch percentage in the composite and was calculated as

$$
\mathrm{RS}(\text { actual content }) \%=\frac{\mathrm{RS}(\text { measured value })}{\text { Starch ratio in composite }} \times 100 \%
$$

\subsection{Statistical Analysis}

All measurements were performed in triplicate. The data were analyzed using SPSS Version 16.0. Duncan's pairwise comparison was used to assess the differences between the mean values, and $p<0.05$ was considered statistically significant based on the analysis of variance (ANOVA) test. 


\begin{abstract}
Author Contributions: Conceptualization: Y.L. and J.L.; Methodology: Y.L. and T.Y.; Validation: T.Y.; Formal analysis: Q.Y. and T.Y.; Resources, Y.L. and J.L.; Data curation: T.Y., J.L. and Q.Y.; Writingoriginal draft preparation: Q.Y.; Writing—review and editing: J.L.; Visualization: T.Y. and Q.Y.; Supervision: Y.L. and J.L.; Funding acquisition: J.L., Y.L. and G.F. All authors have read and agreed to the published version of the manuscript.
\end{abstract}

Funding: This research was funded by the Foundation for Finance, Science and Technology Project of Hainan Province, grant no. ZDYF2019031.

Institutional Review Board Statement: Not applicable.

Informed Consent Statement: Not applicable.

Data Availability Statement: The data presented in this study are available on request from the corresponding author.

Acknowledgments: We thank the National Engineering Laboratory for Wheat and Corn Further Processing for assisting with the property analysis.

Conflicts of Interest: The authors declare no conflict of interest.

\title{
References
}

1. Rhim, J.W.; Gennadios, A.; Weller, C.L.; Cezeirat, C.; Hanna, M.A. Soy protein isolate-dialdehyde starch films. Ind. Crop. Prod. 1998, 8, 195-203. [CrossRef]

2. Fernández-Gutiérrez, J.A.; San Martín-Martínez, E.; Martínez-Bustos, F.; Cruz-Orea, A. Physicochemical Properties of Casein Starch Interaction Obtained by Extrusion Process. Starch-Strke 2010, 56, 190-198. [CrossRef]

3. Li, H.T.; Li, Z.; Fox, G.P.; Gidley, M.J.; Dhital, S. Protein-starch matrix plays a key role in enzymic digestion of high-amylose wheat noodle. Food Chem. 2021, 336, 127719. [CrossRef] [PubMed]

4. Goñi, I.; Garcia-Diz, L.; Mañas, E.; Saura-Calixto, F. Analysis of resistant starch: A method for foods and food products. Food Chem. 1996, 56, 445-449. [CrossRef]

5. Homayouni, A.; Amini, A.; Keshtiban, A.K.; Mortazavian, A.M.; Esazadeh, K.; Pourmoradian, S. Resistant starch in food industry: A changing outlook for consumer and producer. Starch-Starke 2014, 6, 102-114. [CrossRef]

6. Tharanathan, R.N. Food-Derived Carbohydrates-Structural Complexity and Functional Diversity. Crit. Rev. Biotechnol. 2008, 22, 65-84. [CrossRef]

7. Zaman, S.A.; Sarbini, S.R. The potential of resistant starch as a prebiotic. Crit. Rev. Biotechnol. 2016, 36, 578-584. [CrossRef]

8. Zhang, B.; Chen, L.; Zhao, Y.; Li, X. Structure and enzymatic resistivity of debranched high temperature pressure treated high-amylose corn starch. J. Cereal Sci. 2013, 57, 348-355. [CrossRef]

9. Hasjim, J.; Lee, S.O.; Hendrich, S.; Setiawan, S.; Ai, Y.; Jane, J.L. Characterization of a Novel Resistant-Starch and Its Effects on Postprandial Plasma-Glucose and Insulin Responses. Cereal Chem. 2010, 87, 257-262. [CrossRef]

10. Magallanes-Cruz, P.A.; Bello-Pérez, L.A.; Agama-Acevedo, E.; Tovar, J.; Carmona-Garcia, R. Effect of the addition of thermostable and non-thermostable type 2 resistant starch (RS2) in cake batters. LWT 2020, 118, 108834. [CrossRef]

11. Wang, H.; Zhang, B.; Chen, L.; Li, X. Understanding the structure and digestibility of heat-moisture treated starch. Int. J. Biol. Macromol. 2016, 88, 1-8. [CrossRef]

12. Zhang, J.; Chen, F.; Liu, F.; Wang, Z.W. Study on structural changes of microwave heat-moisture treated resistant Canna edulis Ker starch during digestion in vitro. Food Hydrocoll. 2010, 24, 27-34. [CrossRef]

13. Son Trinh, K.; Joo Lee, C.; Jun Choi, S.; Wha Moon, T. Hydrothermal Treatment of Water Yam Starch in a Non-granular State: Slowly Digestible Starch Content and Structural Characteristics. J. Food Sci. 2012, 77, C574-C582. [CrossRef] [PubMed]

14. Molavi, H.; Razavi, S.M.A.; Farhoosh, R. Impact of hydrothermal modifications on the physicochemical, morphology, crystallinity, pasting and thermal properties of acorn starch. Food Chem. 2018, 245, 385-393. [CrossRef] [PubMed]

15. Andrade, M.M.P.; de Oliveira, C.S.; Colman, T.A.D.; da Costa, F.J.O.G.; Schnitzler, E. Effects of heat-moisture treatment on organic cassava starch. J. Therm. Anal. Calorim. 2014, 115, 2115-2122. [CrossRef]

16. Li, Y.D.; Xu, T.C.; Xiao, J.X.; Zong, A.Z.; Qiu, B.; Jia, M.; Liu, L.N.; Liu, W. Efficacy of potato resistant starch prepared by microwave-toughening treatment. Carbohydr. Polym. 2018, 192, 299-307. [CrossRef]

17. Fan, D.; Wang, L.; Chen, W.; Ma, S.; Ma, W.; Liu, X.; Zhao, J.; Zhang, H. Effect of microwave on lamellar parameters of rice starch through small-angle $X$-ray scattering. Food Hydrocoll. 2014, 35, 620-626. [CrossRef]

18. Wei, H.X.; Liang, B.D.; Chai, Y.R.; Xue, L.P.; Wang, X.Q.; Yin, X.M. Effect of Different Heat Treatments on Physicochemical Properties and Structural and Digestibility of Water Caltrop Starch. Starch-Stärke 2020, 72, 1900275. [CrossRef]

19. Zailani, M.A.; Kamilah, H.; Husaini, A.; Seruji, A.Z.R.A.; Sarbini, S.R. Functional and digestibility properties of sago (Metroxylon sagu) starch modified by microwave heat treatment. Food Hydrocoll. 2022, 122, 107042. [CrossRef]

20. Corradini, E.; Curti, P.S.; Meniqueti, A.B.; Martins, A.F.; Rubira, A.F.; Muniz, E.C. Recent Advances in Food-Packing, Pharmaceutical and Biomedical Applications of Zein and Zein-Based Materials. Int. J. Mol. Sci. 2014, 15, 22438-22470. [CrossRef]

21. Xu, H.; Zhang, G. Slow digestion property of microencapsulated normal corn starch. J. Cereal Sci. 2014, 60, 99-104. [CrossRef] 
22. Zheng, M.; Xiao, Y.; Yang, S.; Liu, M.; Feng, L.; Ren, Y.; Yang, X.; Lin, N.; Liu, J. Effect of adding zein, soy protein isolate and whey protein isolate on the physicochemical and in vitro digestion of proso millet starch. Int. J. Food Sci. Technol. 2020, 55, 776-784. [CrossRef]

23. Chen, X.; He, X.; Zhang, B.; Fu, X.; Li, L.; Huang, Q. Structure, physicochemical and in vitro digestion properties of ternary blends containing swollen maize starch, maize oil and zein protein. Food Hydrocoll. 2018, 76, 88-95. [CrossRef]

24. Gao, P.; Wang, F.; Gu, F.; Liang, J.; Li, N.; Ludescher, R.D. Preparation and characterization of zein thermo-modified starch films. Carbohydr. Polym. 2017, 157, 1254-1260. [CrossRef] [PubMed]

25. Federici, E.; Jones, O.G.; Selling, G.W.; Tagliasco, M.; Campanella, O.H. Effect of zein extrusion and starch type on the rheological behavior of gluten-free dough. J. Cereal Sci. 2020, 91, 102866. [CrossRef]

26. Glusac, J.; Fishman, A. Enzymatic and chemical modification of zein for food application. Trends Food Sci. Technol. 2021, 112, 507-517. [CrossRef]

27. Vamadevan, V.; Hoover, R.; Bertoft, E.; Seetharaman, K. Hydrothermal treatment and iodine binding provide insights into the organization of glucan chains within the semi-crystalline lamellae of corn starch granules. Biopolymers 2014, 101, 871-885. [CrossRef] [PubMed]

28. Zhong, Y.; Liang, W.; Pu, H.; Blennow, A.; Liu, X.; Guo, D. Short-time microwave treatment affects the multi-scale structure and digestive properties of high-amylose maize starch. Int. J. Biol. Macromol. 2019, 137, 870-877. [CrossRef] [PubMed]

29. Liu, J.; Lai, R.; Wang, X.; Wang, H.; Liu, Y. Preparation and Characterization of Composites of Hydroxypropyl Tapioca Starch and Zein. Starch-Stärke 2020, 72, 1900204. [CrossRef]

30. Leroy, E.; Jacquet, P.; Coativy, G.; laure Reguerre, A.; Lourdin, D. Compatibilization of starch-zein melt processed blends by an ionic liquid used as plasticizer. Carbohydr. Polym. 2012, 89, 955-963. [CrossRef]

31. Lai, R.; Liu, Y.; Liu, J. Properties of the konjac glucomannan and zein composite gel with or without freeze-thaw treatment. Food Hydrocoll. 2021, 117, 106700. [CrossRef]

32. Luo, Z.; He, X.; Fu, X.; Luo, F.; Gao, Q. Effect of Microwave Radiation on the Physicochemical Properties of Normal Maize, Waxy Maize and Amylomaize V Starches. Starch-Stärke 2006, 58, 468-474. [CrossRef]

33. Pinto, V.Z.; Vanier, N.L.; Klein, B.; Zavareze, E.D.R.; Elias, M.C.; Gutkoski, L.C.; Helbig, E.; Dias, A.R.G. Physicochemical, crystallinity, pasting and thermal properties of heat-moisture-treated pinhão starch. Starch-Stärke 2012, 64, 855-863. [CrossRef]

34. Yin, X.; Ma, Z.; Hu, X.; Li, X.; Boye, J.I. Molecular rearrangement of Laird lentil (Lens culinaris Medikus) starch during different processing treatments of the seeds. Food Hydrocoll. 2018, 79, 399-408. [CrossRef]

35. Ma, Z.; Yin, X.; Hu, X.; Li, X.; Liu, L.; Boye, J.I. Structural characterization of resistant starch isolated from Laird lentils (Lens culinaris) seeds subjected to different processing treatments. Food Chem. 2018, 263, 163-170. [CrossRef] [PubMed]

36. Zhao, K.; Li, B.; Xu, M.; Jing, L.; Gou, M.; Yu, Z.; Zheng, J.; Li, W. Microwave pretreated esterification improved the substitution degree, structural and physicochemical properties of potato starch esters. LWT 2018, 90, 116-123. [CrossRef]

37. Singh, V.; Johnston, D.B. Pasting Properties and Surface Characteristics of Starch Obtained from an Enzymatic Corn Wet-Milling Process. Cereal Chem. 2002, 79, 523-527. [CrossRef]

38. Blazek, J.; Copeland, L. Pasting and swelling properties of wheat flour and starch in relation to amylose content. Carbohydr. Polym. 2008, 71, 380-387. [CrossRef]

39. Lares, M.; Pérez, E. Determination of the Mineral Fraction and Rheological Properties of Microwave Modified Starch from Canna edulis. Plant Foods Hum. Nutr. 2006, 61, 109. [CrossRef]

40. Chung, H.J.; Hoover, R.; Liu, Q. The impact of single and dual hydrothermal modifications on the molecular structure and physicochemical properties of normal corn starch. Int. J. Biol. Macromol. 2009, 44, 203-210. [CrossRef]

41. Mutlu, S.; Kahraman, K.; Öztürk, S. Optimization of resistant starch formation from high amylose corn starch by microwave irradiation treatments and characterization of starch preparations. Int. J. Biol. Macromol. 2017, 95, 635-642. [CrossRef]

42. Park, E.Y.; Ma, J.G.; Kim, J.; Lee, D.H.; Kim, S.Y.; Kwon, D.J.; Kim, J.Y. Effect of dual modification of HMT and crosslinking on physicochemical properties and digestibility of waxy maize starch. Food Hydrocoll. 2018, 75, 33-40. [CrossRef]

43. Huang, T.T.; Zhou, D.N.; Jin, Z.Y.; Xu, X.M.; Chen, H.Q. Effect of repeated heat-moisture treatments on digestibility, physicochemical and structural properties of sweet potato starch. Food Hydrocoll. 2016, 54, 202-210. [CrossRef]

44. Ribotta, P.D.; Colombo, A.; León, A.E.; Añón, M.C. Effects of Soy Protein on Physical and Rheological Properties of Wheat Starch. Starch-Stärke 2007, 59, 614-623. [CrossRef]

45. Brumovsky, J.O.; Thompson, D.B. Production of Boiling-Stable Granular Resistant Starch by Partial Acid Hydrolysis and Hydrothermal Treatments of High-Amylose Maize Starch. Cereal Chem. 2001, 78, 680-689. [CrossRef]

46. Sun, X.; Saleh, A.S.; Sun, Z.; Ge, X.; Shen, H.; Zhang, Q.; Yu, X.; Yuan, L.; Li, W. Modification of multi-scale structure, physicochemical properties and digestibility of rice starch via microwave and cold plasma treatments. LWT 2022, 153, 112483. [CrossRef]

47. Kljak, K.; Duvnjak, M.; Grbeša, D. Effect of starch properties and zein content of commercial maize hybrids on kinetics of starch digestibility in an in vitro poultry model. J. Sci. Food Agric. 2019, 99, 6372-6379. [CrossRef] [PubMed]

48. Sui, Z.; Yao, T.; Zhao, Y.; Ye, X.; Kong, X.; Ai, L. Effects of heat-moisture treatment reaction conditions on the physicochemical and structural properties of maize starch: Moisture and length of heating. Food Chem. 2015, 173, 1125-1132. [CrossRef] [PubMed] 